\title{
PENERAPAN MEDIA PEMBELAJARAN POP-UP BOOK ANAK USIA DINI PADA KELOMPOK B UNTUK MENINGKATKAN KEMAMPUAN KEAKSARAAN AWAL DI TK NUSA INDAH
}

\author{
${ }^{1}$ Rapi Halipani Matin, ${ }^{2}$ Euis Ety Rohaety $^{3}$ Lenny Nuraeni, \\ ${ }^{1}$ IKIP Siliwangi, Jl. Terusan Jendral Sudirman, Cimahi \\ ${ }^{2}$ IKIP Siliwangi, Jl. Terusan Jendral Sudirman, Cimahi \\ ${ }^{3}$ IKIP Siliwangi, Jl. Terusan Jendral Sudirman, Cimahi \\ 19ani.fatin@gmail.com ${ }^{2}$ e2rht@yahoo.com ${ }^{3}$ lennynuraeni86@gmail.com
}

\begin{abstract}
One important aspect developed in early childhood is the ability of early literacy. For this reason, we need a learning media that can improve children's early literacy skills, one of which is pop-up book learning media. The purpose of this study was to determine the effect of using pop-up book learning media on children's early literacy abilities. This study used the Quasi Experiment method with the Nonequevalent Control Group Design research design. The pre-test results showed that there was no significant difference in the experimental group and the control group with a p-value $>0.05$ which was $0.065>0.05$ which was tested by the Mann Whitney test results. While the post-test results showed that the initial literacy ability after the application of the pop-up book learning media had a significant difference with the $p$-value $<0.05$ which was 0.236 . Thus the pop-up book learning media significantly influences early childhood literacy abilities. Based on this study, the study recommends early childhood educators so that the popup book learning media can be used as a medium of learning to improve children's early literacy skills.
\end{abstract}

Keywords: Early literacy skills, pop-up book media.

\begin{abstract}
Abstrak
Salah satu aspek yang penting dikembangkan pada anak usia dini adalah kemampuan keaksaraan awal. Untuk itu diperlukan suatu media pembelajaran yang dapat meningkatkan kemampuan keaksaraan awal anak, salah satunya adalah media pembelajaran pop-up book. Tujuan penelitian ini untuk mengetahui pengaruh penggunaan media pembelajaran pop-up book terhadap kemampuan keaksaraan awal anak. Penelitian ini menggunakan metode Quasi Eksperimen dengan desain penelitian Nonequevalent Control Group Design. Hasil pre test menunjukkan bahwa tidak terdapat perbedaan yang signifikan pada kelompok eksperimen dan kelompok kontrol dengan nilai $p$-value $>0.05$ yaitu dengan hasil $0.065>0.05$ yang diuji oleh hasil uji Mann Whitney. Sedangkan hasil post test menunjukan bahwa kemampuan keaksaraan awal setelah penerapan media pembelajran pop-up book mengalami perbedaan yang signifikan dengan nilai $p$-value $<0.05$ yaitu dengan hasil 0.236 . Dengan demikian media pembelajaran pop-up book memberikan pengaruh secara signifikan terhadap kemampuan keaksaraan awal anak usia dini. Berdasarkan penelitian ini, penelitian merekomendasikan kepada pendidik anak usia dini supaya media pembelajaran pop-up book dapat dijadikan sebagai salah satu media pembelajaran untuk meningkatkan kemampuan keaksaraan awal anak.
\end{abstract}

Kata Kunci : Kemampuan keaksaraan awal, media pop-up book. 


\section{JURNAL GERIA}

ISSN : 2614-6347 (Print) 2614-4107 (Online)

\begin{tabular}{l|l|l} 
Vol.2 & No.2 & Maret 2019 \\
\hline
\end{tabular}

\section{PENDAHULUAN}

Interprenership sering dikaitkan dengan globalisasi. Interprenership adalah pengaplikasian daya kreativitas dan pembaharuan untuk menghadapi suatu masalah sehingga berupaya untuk menggunakan peluang dengan baik. Salah satu aspek perkembangan pada anak usia dini adalah kemampuan keaksaraan awal yang akan membantu anak pada perkembangan bahasa anak. Bahwa pendidikan di Taman Kanakkanak, anak sudah diperkenalkan abjad dari a sampai dengan z. Pembelajaran pengenalan keaksaraan awal dilakukan dengan memperkenalkan huruf-huruf vokal dan konsonan yang merupakan dasar dalam membaca.

Guru adalah pendidik profesional dengan tugas utama mendidik, mengajar, membimbing, mengarahkan, melatih, menilai, mengevaluasi peserta didik pada pendidikan anak usia dini jalur formal, non formal dan informal. Guru adalah salah satu diantara faktor pendidikan yang memiliki peranan yang paling strategis, sebab gurulah sebetulnya yang paling menentukan di dalam terjadinya proses belajar mengajar. (Nuraeni, 2017)

\section{Dalam pembelajaran PAUD}

Perkembangan keaksaraan anak merupakan aspek utama yang sangat penting untuk meningkatkan kemampuan dan kreativitas anak yang sudah dapat membaca biasanya dianggap anak yang mempunyai tingkat kecerdasan yang tinggi, akan tetapi kecerdasan seseorang tidak dapat diukur hanya bisa membaca saja. Seseorang dapat dikatakan mempunyai tingkat kecerdasan yang tinggi selain bisa membaca juga mampu mengolah kata secara komprehensif, mengekspresikan kata-kata dalam bahasa tubuh (ucapan dan perbuatan) yang dapat dipahami oleh oranglain serta jelas dalam penyampaiannya seperti keterampilan membaca.

Keterampilan membaca adalah salah satu keterampilan yang harus dikuasai oleh setiap anak, karena membaca merupakan sumber informasi yang akan dikembangkan pada setiap berfikir anak. Namun kata "membaca" disini merupakan satuan huruf atau kata dasar sederhana untuk mempermudah kegiatan belajar anak.Telah disadari bahwa penguasaan bahasa itu sangat diperlukan dalam kehidupan dan perlu di tanamkan sejak dini. Sebagian orang mengatakan bahwa belum saatnya anak usia dini untuk belajar membaca namun perlu kita ketahui penerapan membaca kepada anak sebaiknya menggunakan metode pembelajaran yang kreatif dan berbasis media permainan edukatif sehingga pada saat anak sedang bermain tanpa kita sadari bahwa hal tersebut sudah merupakan kegiatan belajar bagi anak. Maka dari itu seiring perkembangan zaman, dengan adanya media pop-up book diharapkan dapat meningkatkan perkembangan keaksaraan reseftif anak. Anak-anak akan belajar menyusun huruf-huruf dan menjadikan kata-kata yang bermakna dibawah bimbingan guru.

Media pembelajaran adalah segala sesuatu yang dapat digunakan untuk menyalurkan pesan dari guru kepada siswa atau anak sehingga dapat merangsang pikiran, perasaan, perhatian dan minat serta perhatian anak sedemikian rupa sehingga proses pembelajaran terjadi dan berlangsung lebih efesien. Memilih media pembelajaran untuk kegiatan belajar tidak boleh asal-asalan, sebab media harus memenuhi kriteria khusus agar bisa dijadikan sebagai alat untuk menstimulus daya pikir dan keingintahuan siswa dalam belajar. Kriteria media untuk belajar dapat 


\section{JURHAL GERIA}

ISSN : 2614-6347 (Print) 2614-4107 (Online)

\begin{tabular}{l|l|l} 
Vol.2 & No.2 & Maret 2019 \\
\hline
\end{tabular}

mendukung isi materi pelajaran, mudah dipahami, pengajar dapat mengaplikasikannya dan sesuai dengan kemampuan berpikir siswa. Setelah memahami pengertian media, tentu saja Anda harus mengetahui apa saja contoh media yang bisa dipakai untuk kegiatan belajar. Di bawah ini adalah contoh media untuk pembelajaran (Yani \& Cartyanto, 2013: 34)

Pop-Up Book adalah media pembelajaran yang sengaja dirancang khusus berbentuk 3D dengan bervariasi bentuk dan gambar yang menarik serta unik untuk kepentingan Pendidikan Anak Usia Dini (PAUD). Dapat disimpulkan bahwa dengan adanya variasi pop-upbook untuk berbagai keperluan, media buku pop-up dapat digunakan sebagai media pembelajaran.Fungsi pop-up sebagai media pembelajaran memang masih jarang digunakan, selain itu pop-up book ini belum populer untuk masyarakat awam. Buku pop-up book mempunyai peluang yang sangat besar untuk dikembangkan sebagai media pembelajaran.

Menarik perhatian semua kalangan khususnya pada anak-anak, media buku ceita 3D atau yang saat ini disebut Pop-up book dapat menarik pusat perhatian bagi anak-anak. Pada mulanya anak-anak biasa saja melihat sampul buku namun, setelah halaman ertama anak-anak akan terkejut dengan gambar yang tiba-tiba muncul dan dapat bergerak. Selain itu, menariknya lagi adalah anak-anak akan mengeluarkan suara terkejut saat melihat gambar 3D di setiap halaman yang berbeda-beda. Menarik perhatian anak-anak dalam memusatkan perhatian mereka kesatu titik, satu hal yang membantu konsentrasi terhadap suatu hal, media buku 3D ini bisa membantu. Buku cerita 3D ini tidak hanya membuat siswa penasaran dengan gambar-gambar disetiap halamannya, namun mereka juga akan penasaran cerita dari setiap gambar tersebut (Jackson, 2016: 105). Hal ini dapat terlihat dari hasil tulisan yang dibuat anak lebih banyak dan baik secara bentuk huruf maupun angka.Kegiatan melalui media pembelajaran pop-up book secara tidak langsung telah mengembangkan kemampuan keaksaraan awal pada anak.Anak diberikan kebebasan dalam mengembangkan kemampuan keaksaraan awal dengan berbagai macam kegiatan. Berdasarkan latar belakang tersebut, maka judul yang dipilih dalam penelitian ini adalah "Penerapan Media Pembelajaran PopUp Book Anak Usia Dini untuk Meningkatkan Kemampuan Keaksaraan Awal di TK Nusa Indah" METODE

Metode penelitian yang digunakan adalah metode kuasi eksperimen dengan menggunakan desain kelompok kontrol non-ekuivalent. Pada kuasi eksperimen ini subjek tidak dikelompokan secara acak, tetapi peneliti menerima keadaan subjek seadanya, (Ruseffendi, 2010: 52) . Pada penelitian ini digunakan dua kelas. Kelas yang pertama sebagai kelas eksperimen, sedangkan kelas lainnya sebagai kelas kontrol. Pada kelas eksperimen diberikan pembelajaran dengan menggunakan saintifik dengan media pembelajaran Pop-Up Book dan kelas control menggunakan pembelajaran biasa. Dengan demikian desain eksperimen dalam penelitian ini dapat digambarkan sebagai bentuk pada awal dan akhir pembelajaran kedua kelas diberi tes sehingga desain penelitiannya (Ruseffendi, 2005: 50) adalah sebagai berikut:

A : O X O

A : $\mathrm{O} \quad \mathrm{O}$ 


\section{JURHAL GERIA}

ISSN : 2614-6347 (Print) 2614-4107 (Online)

Vol.2 $\mid$ No.2 $\mid$ Maret 2019

\section{Keterangan :}

A: Sampel yang dipilih berdasarkankelas $\mathrm{O}:$ Pretest $=$ posttest (tes kemampuan keaksaraan awal)

$\mathrm{X}$ : Perlakuan Pembelajaran dengan Media Pop-Up Book

Variabel dalam penelitian ini terdiri dari variabel terikat dan variabel bebas.Variabel terikat dalam penelitian ini adalah kemampuan keaksaraan awal, sedangkan variabel bebas dalam penelitian adalah media pembelajaran pop-up book. Subjek penelitian dalam penelitian ini adalah anak kelompok B dengan rentang usia lima sampai enam tahun di TK Nusa Indah Kota Cimahi.

Instrumen penelitian ini menggunakan pedoman observasi dengan penilaian menggunakan skala likert dengan skor yang di gunakan dalam penelitian ini yaitu 1-4, skor 1 untuk penilaian $\mathrm{BB}$ (belum berkembang), skor 2 untuk penilaian $\mathrm{MB}$ (mulai berkembang), skor 3 untuk penilaian BSH (berkembang sesuai harapan), skor 4 untuk penilaian BSB (berkembang sangat baik). Kemampuan keaksaraan awal anak usia dini memiliki enam indikator yaitu indikator satu pengucapan (vokal), indikator dua meniru bentuk, indikator tiga penulisan dengan berbagai media dan kegiatan, indikator empat melafalkan bunyi sesuai dengan huruf yang dibaca.

\section{HASIL DAN PEMBAHASAN \\ HASIL}

\section{Profil Kemampuan Keaksarsaan Awal Anak Usia Dini Pada Kelompok Eksperimen dan control di TK Nusa Indah Kota Cimahi Sebelum Menggunakan Media Pembelajaran Pop-Up Book.}

Berdasarkan hasil penelitian dan analisis data terhadap sampel penelitian, dengan tujuan untuk mengetahui apakah kemampuan Keaksaraan Awal anak yang pembelajarannya menggunakan media pembelajaran Pop-Up Book lebih baik daripada yang menggunakan media pembelajaran biasa. Untuk lebih memudahkan dalam menganalisis data hasil skor pretest dan skor postest, maka akan disajikan deskripsi statistik untuk hasil skor pretest dan skor postest kemampuan keaksaraan awal pada anak pada kelas eksperimen dan kelas kontrol dalam bentuk tabel sebagai berikut:

Tabel 1.1

Deskripsi Data Kemampuan Keaksaraan Awal

\begin{tabular}{|c|c|c|c|c|c|}
\hline Variabel & & \multicolumn{2}{|c|}{ Kelas Eksperimen } & \multicolumn{2}{|c|}{ Kelas Kontrol } \\
\hline \multirow{6}{*}{ 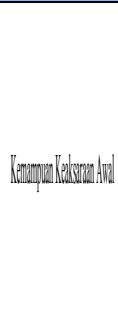 } & & Pretes & Postes & Pretes & Postes \\
\hline & $\mathrm{N}$ & $\begin{array}{ll}21 \\
\end{array}$ & 21 & 22 & 22 \\
\hline & Nilai Max & 64 & 64 & 64 & 64 \\
\hline & Nilai Min & 36 & 53 & 38 & 48 \\
\hline & Rata-rata & 55,04 & 57,33 & 58,18 & 57,45 \\
\hline & StDev & 3,18 & 6,12 & 4,50 & 4,35 \\
\hline
\end{tabular}

Keaksaraan awal $=4$

Pada Tabel 1.1 diperoleh ratarata tes kemampuan awal untuk kelas eksperimen dan kelas kontrol berbeda sebesar 3.14. Simpangan baku kemampuan awal kelas eksperimen lebih kecil dibandingkan kelas kontrol, sehingga kelas eksperimen lebih menyebar. Pada tabel tersebut juga terlihat rata-rata postest kelas eksperimen dan kelas kontrol berbeda sebesar 0.12. Kelas kontrol rata - ratanya lebih tinggi dibandingkan kelas eksperimen. Pada kelas eksperimen mempunyai simpangan baku lebih besar dibandingkan kelas kontrol. Dapat dilihat bahwa kelas eksperimen memiliki rata - rata kemampuan keaksaraan awal yang lebih tinggi dan penyebarannya lebih besar dibandingkan kelas kontrol.

Selain itu peneliti melakukan uji perbedaan dua rata-rata postes dilakukan 


\section{JURHAL GERIA}

ISSN : 2614-6347 (Print) 2614-4107 (Online)

\begin{tabular}{l|l|l} 
Vol.2 & No.2 & Maret 2019 \\
\hline
\end{tabular}

untuk melihat apakah kemampuan keaksaraan awal anak yang pembelajarannya menggunakan media pembelajaran pop-up book lebih baik dari yang menggunakan pembelajaran biasa. Untuk mengetahui hasil perbedaan dua rata-rata data postes, berikut hipotesis dan kriteria yang harus diperhatikan.

Hipotesis:

$\mathrm{H}_{0}$ : Kemampuan keaksaraan awal dengan menggunakan media pembelajaran biasa tidak lebih baik daripada yang menggunakan media pembelajaran pop-up book.

$\mathrm{H}_{1}$ : Kemampuan keaksaraan awal anak denganmenggunakan media pembelajaran pop-up book lebih baik daripada yang menggunakan pembelajaran biasa.

Kriteria:

- Jika signifikansi 0,05 maka $\mathrm{H}_{\mathrm{o}}$ diterima

- Jika signifikansi 0,05 maka $\mathrm{H}_{\mathrm{o}}$ ditolak

Berikut ini adalah rangkuman perhitungan uji perbedaan dua rata-rata postes kelas eksperimen dan kelas kontrol disajikan pada Tabel 1.2 berikut.

\section{Tabel 1.2}

Independent Sample Test

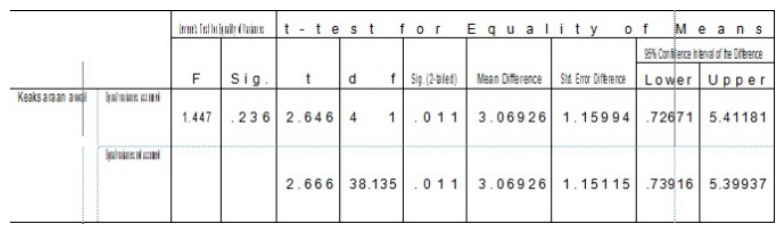

Berdasarkan Tabel 1.2 terlihat bahwa di peroleh nilai sig (2 tailed) adalah 0,011, maka signifikasi satu pihaknya adalah $=0,0055$, dengan demikian nilai terebut kurang dari 0,05 artinya peningkatan kemampuan Keaksaraan awal dengan menggunakan media pembelajaran pop-up book lebih baik dibandingkan dengan anak yang menggunakan pembelajaran biasa.

\section{PEMBAHASAN}

Awalnya perolehan data pre test kemampuan keaksaraan awal anak pada kelompok eksperimen dan kelompok kontrol setelah dilakukan perhitungan Kolmogorov-smirnov pada uji normalitas dan uji homogenitas menunjukan bahwa kedua kelompok berdistribusi normal dari populasi yang homogen. Ini menunjukan bahwa anak pada kelompok eksperimen dan kelompok kontrol memiliki karakter kemampuan motorik halus yang tidak jauh berbeda atau sama dan setelah dibuktikan dengan hasil uji $\mathrm{t}$ independen sampel menunjukan nilai sig lebih besar dari $p$-value $(0,605>0,05)$. Hal ini menunjukan bahwa tidak terdapat perbedaan kemampuan motorik halus anak diantara kedua kelompok. Hal ini disebabkan karena pada kelompok eksperimen belum dilakukan perlakuan sehingga kemampuan keaksaraan anak pada kedua kelompok tidak jauh berbeda. Hal ini dapat dibuktikan dengan penelitian yang dilakukan oleh canggih (2015) dengan judul Efektivitas Media Pop-Up Book dalam Meningkatkan Kemampuan Membaca Cerita menyatakan bahwa media pembelajaran pop-up book dapat meningkatkan keterampilan membaca pada keaksaraan awal anak (2015). Hal ini dapat terlihat dari hasil tulisan yang dibuat anak lebih banyak dan baik secara bentuk huruf maupun angka. Dengan media pembelajaran pop-up book anak memiliki banyak kesempatan untuk menuangkan ide dan pengalaman yang kaya dan bermakna ke dalam bentuk bahasa tulisan.

Berbeda setelah diberikan perlakuan kedua kelompok menunjukan perbedaan. Hal ini dibuktikan dengan hasil perhitungan akhir dalam penelitian menunjukan bahwa nilai sig pada data post test lebih kecil dari p-value $(0,236<$ $0,05)$ Ini artinya bahwa terdapat 


\section{JURNAL GERIA}

ISSN : 2614-6347 (Print) 2614-4107 (Online)

Vol.2 2 No.2 1 Maret 2019

perbedaan kemampuan keaksaraan awal anak setelah diterapkan media pembelajaran pada kelompok eksperimen dan nilai rata-rata kelompok eksperimen sebesar 8.00 lebih besar dibandingkan nilai rata-rata kelompok kontrol sebesar 7.00. Ini artinya bahwa terdapat perbedaan kemampuan keaksaraan awal yang signifikan antara kelompok ekperimen yang menggunakan media pembelajaran pop-up book dengan kelompok kontrol yang menggunakan media pembelajaran biasa.

$$
\text { Terdapatnya perbedaan }
$$

kemampuan keaksaraanawal anak setelah diberikan perlakuan dikarenakan media pembelajaran pop-up book memberikan pembelajaranserta kegiatanyang mengembangkan kemampuan keaksaraan awal, sehingga anak dengancara tersebut dibuat sibuk mengerjakannya dalam menulis permulaan serta membaca permulaan.Pada kelompok eksperimen di TK Nusa Indah Cimahi Selatan sebelum menggunakan media pembelajaran pop-up book, untuk mengembangkan kemampuan keaksaraanawal, guru menggunakan pembelajaran kelompok. Melalui pembelajaran kelompok yang dilakukan oleh guru, anak-anak dibiasakan untuk melakukan pekerjaan secara mandiri sesuai dengan contoh yang diberikan guru, akan tetapi bagi anak yang memiliki kesulitan dalam menulis permulaan sulit untuk meminta bantuan kepada temannya untuk menjelaskan kembali serta mengingatkan tahapantahapan untuk mengerjakan perkerjaannya sehingga hasil pekerjaan anak kurang baik dan tepat, sedangkan pada kelompok kontrol di TK Nusa Indah kelas mawar untuk mengembangkan kemampuan keaksaraan awal, guru menggunakan pembelajaran biasa. Melalui pembelajaran ini guru membiasakan anak mengerjakan pekerjaannya secara bersama-sama sesuai dengan contoh yang diberikan guru, akan tetapi pembelajaran biasa yang dilakukan terus menerus akan membuat anak merasa bosan sehingga anak-anak akan merasa malas untuk mengerjakan pekerjaannya secara tepat dan baik.

Sejalan dengan penjelasan diatas, menurut Vygotsky,menyebut pertanyaan untuk anak sebagai internal spech yaitu suatu proses yang akan menumbuhkan rasa ingin tahu dan menantang anak untuk berfikir lebih jauh. Sesuai tingkat perkembangan anak artinya pembelajaran untuk anak usia dini harus disesuaikan dengan tingkat perkembangan anak. Berdasarkan penjabaran tersebut, maka pembelajaran mengenal keaksaraan awal pada anak kelompok $\mathrm{B}$ harus mempertimbangkan prinsip kemampuan morfologi pada pembelajaran anak.

Terdapat lima aspek morfologi kelas verba penelitian hanya memperoleh tiga jenis kelas verba, yaitu: Nomina Kata dasar, verba turunan yang mencakup: verba berafiks, verba bereduplikasi, verba berproses gabungan, serta verba majemuk. (Lenny Nuraeni, 2015)

Pembelajaran morfologi sangat erat kaitannya dengan Pembelajaran mengenal keaksaraan awal akan menjadi bermakna apabila anak dapat terlibat dalam suatu aktivitas, dimana anak dapat memainkan seluruh sensorinya. Anakbelajar interaksi langsung dengan ojek, sehingga pembelajaran dapat memberikan kesempatan bagi anak untuk mengkreasi dan memanipulasi objek tersebut.interaksi dengan objek tersebut, pada akhirnya akan mendorong anak memperoleh pengalaman yang dapat merangsang proses berfikirnya. Oleh karena itu guru perlu 


\section{JURNAL GERIA}

ISSN : 2614-6347 (Print) 2614-4107 (Online)

Vol.2 2 No.2 1 Maret 2019

mengembangkan media pembelajaran pengajaran yang variatif agar kegiatan pembelajaran mampu memotivasi anak, mudah ditiru anak dan memberikan pengalaman serta kesan kepada anak.Media pembelajaran pop-upbook dapat mengembangkan kemampuan keaksaraanawla anak ketika anak membuat hasil karya pada kegiatan konstruksi.

Berdasarkan penjelasan di atas, kemampuan keaksaraan awal anak penting dilakukan sedini mungkin sesuai dengan tahapan usia anak agar kemampuan bahasa anak dan pribadi anak di masyarakat mudah diterima. Hal yang pelu diperhatikan untuk mengembangkan kemampuan keaksaraan awal anak adalah kesiapan anak untuk membaca, karena karakteristik setiap anak berbeda sehingga guru perlu mempersiapkan kegiatan pembelajaran berdasarkan tahapan usia anak. Orang tua atau guru tidak boleh memaksakan anak untuk bisa cepat membaca permulaan akan tetapi orang tua atau guru dapat menyediakan waktu untuk anak mencoba baik hasilnya salah atau benar sehingga guru atau orang tua dapat menyediakan kegiatan yang variatif dan inovatif untuk mengembangkan kemampuan keaksaraan awal anak sebagai latihan mereka dan siap untuk melanjutkan jenjang pendidikan yang lebih selanjutnya.

\section{Gambar 1.1 \\ Proses Pembelajaran Pada Saat Dilakukan Tindakan Di Kls Eksperimen}

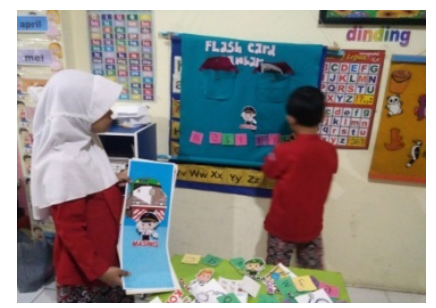

Terlihat pada gabmar tersebut anak sudah bisa membuat satu kata dengan susunan huruf yang sesuai dan benar, pada gambar tersebut sedang dilakukannya proses pembelajaran dengan diterapkan tindakan media pembelajaran pop-up book untuk mengembangkan keaksaraan awal pada anak kelompok B di kelas eksperimen. Selain anak sudah mampu mengembangkan keaksaraan awalnya anak juga terlihat antusias dan sangat aktif ketika proses KBM sedang berlangsung. Berarti sudah terbukti bahwa penerapan media pembelajaran ini berhasil untuk diterapkan untuk kemampuan keaksaraan awal. Dan menurut penelitian sebelumnya bahwa yang dilakukan oleh Devi canggih penerapan pop-up book untuk kemampuan membaca permulaan bagi anak kelompok B sudah berhasil diterapkannya. Maka dari itu dikaitkan dengan teori yang sudah ada bahwa Menurut hariyanto dalam (Maysaroh, 2018) pendidikan di Taman Kanakkanak anak sudah diperkenalkan abjad dari a sampai dengan z. Pada proses pengenalan keaksaraan awal terutama bagi anak kelompok A (usia 4-5 tahun) di Taman Kanak-kanak. Pembelajaran pengenalan keaksaraan awal dilakukan dengan memperkenalkan huruf-huruf vokal dan konsonan yang merupakan dasar dalam membaca.

Melalui pengenalan huruf vokal dan konsonan, anak akan memahami bentuk huruf dan selanjutnya dapat membentuk suku kata dan kata tertentu. Dalam mengoptimalkan pelaksanaannya, anak perlu dibimbing oleh guru sehingga kemampuan anak dalam membaca akan meningkat. Untuk huruf vokal dan konsonan pada anak dapat diawalidengan memperkenalkan huruf vokal. Huruf vokal adalah bunyi ujaran adanya udara yang keluar dari paru-paru 


\section{JURNAL GERIA}

ISSN : 2614-6347 (Print) 2614-4107 (Online)

\begin{tabular}{l|l|l} 
Vol.2 & No.2 & Maret 2019 \\
\hline
\end{tabular}

yang tidak terkena hambatan. Jumlah huruf vokal ada 5, yaitu a, i, u, e, dan o. Pengenalan huruf vokal ini dilakukan dengan memperkenalkan bentuk huruf tersebut dengan menunjukkan bentuk setiap huruf atau menuliskan di papan tulis, sehingga anak mengenal dan memahami bentuk huruf vokal dengan tepat.

Di samping huruf vokal anak juga perlu diperkenalkan huruf konsonan. Huruf konsonan merupakan bunyi ujaran akibat adanya udara yang keluar dari paru-paru tanpa adanya hambatan. Jumlah huruf konsonan ada 21 buah, yaitu b, c, d, f, g, h, j, k, l, m, n, p, q, r, s, t, v, w, x, y, dan z. Pengenalah huruf vokal dan konsonan sangat diperlukan sebagai dasar anak dalam mengenal keaksaraan dan dapat membaca dengan lancar. Upaya untuk meningkatkan kemampuan anak dalam keaksaraan awal dapat dilakukan dengan memperkenalkan bentuk huruf sehingga anak dapat memahami kata-kata yang diajarkan.

\section{KESIMPULAN}

Berdasarkan hasil penelitian diperoleh hasil bahwa pengaruh penggunaan media pembelajaran pop-up book terhadap kemampuan keaksaraan awal anak usia dini membuktikan bahwa melalui metode proyek profil kemampuan motorik halus anak pada kelompok eksperimen terdapat perbedaan yang signifikan dibandingkan dengan profil kemampuan motorik halus anak pada kelompok kontrol yang menggunakan metode konvensional. Hal ini dapat dilihat dari hasil nilai rata-rata gain data pre test dan data post test pada kelompok eksperimen nilai rata-rata gain memiliki hasil lebih besar dibandingkan nilai rata-rata gain kelompok kontrol.

\section{DAFTAR PUSTAKA}

Devi, C (2015). Efektivitas Media Pop-Up Book dalam Meningkatkan Kemampuan Membaca Cerita, Universitas Negri Maulana Malik Ibrahim, Malang

Jackson,P (2014). The Pop-Up Book Step by step instructions for creating. English: Goodreads

Meimulyani, Y dan Cryoto (2013). Media Pembelajaran Adaptif. Jakarta: PT.Lukima Metro Media.

Maysaroh (2018). Peningkatan Kemampuan Keaksaraan Awal Anak melalui penggunaan Media FlashCard, Universitas Islam Nengeri Sunan Ampel, Surabaya

Nuraeni, L. (2017). Efektivitas Diklat Berjenjang Tingkat Dasar Terhadap Peningkatan Kompetensi Pedagogik Pendidik PAUD (Studi Deskriptif Pada Pendidik Paud Di Kota Cimahi). Jurnal Empowerment, 4(2252), 1-16.

Nuraeni, L. (2015). Pemerolehan Morfologi (Verba) Pada Anak Usia 3, 4 Dan 5 Tahun (Suatu Kajian Neuro Psikolinguistik). STKIP Siliwangi Bandung, 1(1), 13-30.

Ruseffendi, E.T. (2010a). Dasar-dasar Penelitian Pendidikan Bidang Non-Eksaktalainnya.Bandung: Tarsito. 